\title{
ATRAZINE BOUND RESIDUES FORMATION AND DISSIPATION IN SUBTROPICAL SOIL UNDER SWINE WASTEWATER APPLICATION
}

\author{
MORGANA S. GONÇALVES ${ }^{1}$, SILVIO C. SAMPAIO ${ }^{2}$, SILVIA R. M. COELHO ${ }^{3}$, \\ FLORIANO L. SUSZEK ${ }^{4}$, CLAUDIA M. d. S. CORDOVIL ${ }^{5}$
}

\begin{abstract}
The effects of swine wastewater on atrazine dissipation and formation of bound residues in subtropical clay soil were investigated in this study. The experiment was carried out in laboratory, under room conditions, where samples of Rhodic Hapludox soil received $168.61 \mathrm{mg} \mathrm{kg}^{-1}$ of atrazine and were incubated for 60 days in the following treatments: T1 (sterilized soil + swine wastewater), T2 (sterilized soil + distilled water), T3 (Non sterilized soil + swine wastewater) and T4 (Non sterilized soil + distilled water). The extractable residues and bound residues of atrazine were extracted and analyzed by high performance liquid chromatography. The results showed no effect of swine wastewater on atrazine dissipation. However, the addition of swine wastewater favored the increase of bound residues, which can increase the persistence of atrazine in the environment and reduce its bioavailability.
\end{abstract}

KEYWORDS: herbicide, degradation, sorption, organic matter.

\section{DISSIPAÇÃO E FORMAÇÃO DE RESÍDUOS LIGADOS DE ATRAZINA EM SOLO SUBTROPICAL SOB APLICAÇÃO DE ÁGUA RESIDUÁRIA DA SUINOCULTURA}

RESUMO: Os efeitos da aplicação de água residuária da suinocultura (ARS) na dissipação de atrazina e formação de resíduos ligados em solo subtropical argiloso foram investigados neste trabalho. O experimento foi conduzido em laboratório, sob condições controladas, onde amostras de Latossolo Vermelho distroférrico receberam a aplicação de $168,61 \mathrm{mg} \mathrm{kg}^{-1}$ de atrazina e foram incubadas durante 60 dias, de acordo com os seguintes tratamentos: T1 (Solo esterilizado + ARS); T2 (Solo esterilizado + água destilada); T3 (Solo não esterilizado + ARS), e T4 (Solo não esterilizado + água destilada). Os resíduos extraíveis de atrazina e resíduos ligados foram extraídos e analisados por cromatografía líquida de alta eficiência. Os resultados mostraram que não houve efeito da aplicação de ARS na dissipação de atrazina. Entretanto, a adição de ARS ao solo favoreceu o aumento da formação de resíduos ligados, o que pode aumentar a persistência da atrazina no ambiente e diminuir sua biodisponibilidade.

PALAVRAS-CHAVE: herbicida, degradação, sorção, matéria orgânica.

\section{INTRODUCTION}

Atrazine is a triazine herbicide used for the control of long-leafed weeds in corn crops. Its chemical structure is represented by a triazine ring replaced by chlorine, ethylamine and isopropylamine, which makes it become recalcitrant for biological degradation in the environment (COLLA et al., 2008; LIMA et al., 2009). It is the herbicide that is most detected in superficial and underground waters, as a result from lixiviation, surface flow and draining of agricultural areas (FAVA et al., 2007; MUDHOO \& GARG, 2011).

\footnotetext{
${ }^{1}$ Prof $^{a}$. Dri ${ }^{\mathrm{a}}$, Coordenação do Curso de Engenharia Ambiental, Universidade Tecnológica Federal do Paraná, Francisco Beltrão-PR, morgana@utfpr.edu.br.

${ }^{2}$ Prof. Adjunto, Programa de Pós-Graduação em Engenharia Agrícola, UNIOESTE, Cascavel-PR.

${ }^{3}$ Prof ${ }^{\text {a }}$. Adjunta, Programa de Pós-Graduação em Engenharia Agrícola, UNIOESTE, Cascavel-PR.

${ }_{5}^{4}$ Mestrando, Programa de Pós-Graduação em Engenharia Agrícola, UNIOESTE, Cascavel-PR.

${ }^{5}$ Prof $^{\mathrm{a}}$. Dra ${ }^{\mathrm{a}}$., Instituto Superior de Agronomia, Universidade Técnica de Lisboa, Portugal.

Recebido pelo Conselho Editorial em: 13-9-2011
}

Aprovado pelo Conselho Editorial em: 5-7-2012 
In a swine farm, the daily amount of wastewater depends, among other factors, on the number and age of animals, on the amount of water wasted in the fountain and bay sanitation, body and feed wastes, fur, dust and other materials from the process. These factors, when associated, determine the concentration of solids, organic charge, heavy metals, nutrients and microorganisms in the wastewater, that define which treatment is needed in order to prevent wastewater from causing environmental pollution.

Recent studies have evaluated the potential and effects of swine wastewater in the plant (PELISSARI et al., 2009; DAL BOSCO et al., 2008; BAUMGARTNER et al. 2007), soil (SAMPAIO et al., 2010a; CAOVILLA, et al., 2010; PRIOR, et al. 2009; SUSZEK, et al. 2007), groundwater (MAGGI et al., 2011; DOBLINSKI et al. 2010; SAMPAIO et al. 2010b; SMANHOTTO et al. 2010; ANAMI et al. 2008; DAL BOSCO et al. 2008; ANAMI et al. 2007) and hydraulic systems (SAMPAIO et al, 2010c; SAMPAIO et al. 2007a; SAMPAIO et al. 2007b; FRIGO et al. 2006).

When adequately applied, swine wastewater promotes improvements in physicochemical and biological properties of the soil. However, organic wastes in soil can modify the pesticides fate in the environment, due to the high content and quality of organic material and diversity of microorganisms (MÜLLER et al., 2007; KADIAN et al., 2008; WANG et al., 2009; AGUILERA et al., 2009; OSMAN et al., 2009). According to the International Union of Pure and Applied Chemistry, 'bound residue' is the name given to the chemical species originated from pesticides, which can only be extracted by methods that change the nature of the molecule and/or the matrix, including soil, plants and animals (BARRACLOUGH et al., 2005).

Studies about the effects of organic material use on soil, in atrazine degradation, have been reported by some researchers (HOUOT et al., 1998; BIGWANEZA et al., 2003; TSUI \& ROY, 2007; KADIAN et al., 2008; AGUILERA et al., 2009). In a general sense, atrazine degradation is improved by adding microorganisms and nutrients. However, when any kind of organic material is added into a soil, to which herbicides will be sprayed later, it can influence in the increase of sorption due to the formation of residues, linked to the additional organic material and so decreasing the bioavailability and retarding biological degradation (WANG et al., 2009). Besides, wastewaters application in soil can also suppress the action of atrazine to degrade microorganisms, either by the incorporation of inorganic nitrogen or by the competition among the species of bacteria and fungi (SHAPIR et al., 2000; GHOSH \& PHILIP, 2006).

In sub-tropical Brazilian ecosystems, the researches regarding the effects of organic residues over the factors that interfere on the dynamics of soil pesticides, such as bound residues, are still incipient. Thus, this essay aimed at evaluating dissipation of atrazine and formation of nonextractable residues (bound residues), in Rhodic Hapludox soil when moistened with water from the swine farm wastes.

\section{MATERIAL AND METHODS}

The soil used in this experiment, clay-textured and classified as Rhodic Hapludox (EMBRAPA, 2006), was collected in Ubiratã city, State of Paraná, in an area with no records of atrazine application, but with a vegetable coverage composed by grass, and samples collected from 0-20 cm underground. Roots that remained in the soil were manually removed, and soil dried in open air, lumps were broken, and sieved in a fabric with 2-mm openings. Swine wastewater and chemical and physical characteristics of soil were determined (Tables 1 and 2).

TABLE 1. Characterization of soil used in the experiment.

\begin{tabular}{|c|c|c|c|c|c|c|}
\hline \multirow{2}{*}{$\mathrm{pH}\left(\mathrm{CaCl}_{2}\right)$} & Sand & Silt & Clay & CEC & $\mathrm{C}$ & $\mathrm{OM}$ \\
\hline & & $\left(\mathrm{g} \mathrm{kg}^{-1}\right)$ & & $\left(\mathrm{cmol}_{\mathrm{c}} \mathrm{kg}^{-1}\right)$ & \multicolumn{2}{|c|}{$\left(\mathrm{g} \mathrm{kg}^{-1}\right)$} \\
\hline 5.20 & 150.00 & 250.00 & 600.00 & 11.77 & 17.81 & 30.63 \\
\hline
\end{tabular}

Cation exchange capacity (CEC); Carbon (C); Organic Material (OM). 
TABLE 2. Characterization of swine wastewater.

\begin{tabular}{ccccc}
\hline \multirow{2}{*}{$\mathrm{pH}$} & BDO & CDO & TOC & TKN \\
\cline { 2 - 5 } & \multicolumn{5}{c}{$\left(\mathrm{mg} \mathrm{L}^{-1}\right)$} \\
\hline 7.22 & 627.70 & 1.965 .00 & 377.00 & 710.00 \\
\hline
\end{tabular}

Biochemical demand of oxygen (BDO); Chemical Demand of Oxygen (CDO); Total Organic Carbon (TOC); Total Kjeldahl Nitrogen (TKN).

Swine wastewater was collected in a rural property in Toledo city (Paraná - Brazil), treated in an integrated bio-system constituted by a bio-digester, a sedimentation tank, two stabilization ponds, and separate tanks for algae and fish. The sample was collected in a sterile vial in the way out of the second stabilization pond.

\section{Treatments and measured parameters}

Previous studies in this field enabled the definition of the following treatments, in order to reach the objectives: sterile soil + swine wastewater $(\mathrm{T} 1)$; sterile soil + distilled water $(\mathrm{T} 2)$; nonsterile soil + swine wastewater (T3); non-sterile soil + distilled water (T4).

The parameters evaluated in each of the treatments were the extractable and bound residues, and dissipated atrazine.

\section{Conduction of the experiment}

Amounts of $100 \mathrm{~g}$ of soil were transferred to $250-\mathrm{ml}$ Erlenmeyer vials. The samples were moistened with an adequate volume of sterile distilled water or SW, according to the treatment, until humidity was raised up to $60 \%$ field capacity. The field capacity of the soil was determined by the technique of cob separation by wetness front. The incubation was conducted in the dark, at $23^{\circ}$ $\mathrm{C}$, and at constant agitation of $100 \mathrm{rpm}$, during 60 days.

The soil was sterilized in autoclave for treatments $\mathrm{T} 1$ and $\mathrm{T} 2$, and for all the treatments, $168.61 \mathrm{mg} \mathrm{kg}^{-1}$ of commercial atrazine were applied. During incubation, soil humidity was preserved in $60 \%$ of field capacity, by adding sterile distilled water, according to the vials weighing.

The removal of extractable residues of atrazine was carried after 60 days of incubation. A few 25-g samples were dried in open air, sieved in a fabric with 2-mm openings and put into 250-ml Erlenmeyer vials with $25 \mathrm{ml}$ of methanol. After five minutes in ultrasound bath, the samples were stirred for 1 hour at $220 \mathrm{rpm}$ and centrifuged for 30 minutes at $2000 \mathrm{rpm}$. The supernatant was reserved and the procedure was repeated twice. The supernatants were grouped and $10 \mathrm{~mL}$ at $40^{\circ} \mathrm{C}$ were evaporated in a rotary evaporator until the final volume was $1 \mathrm{~mL}$ in order to determine atrazine by high-performance liquid chromatography (HPLC). The soil was reserved for further extraction of bound residues.

The same described extraction procedure was performed, in triplicate, to obtain a fortified soil sample with $50 \mathrm{mg} \mathrm{L}^{-1}$ of atrazine to determine the percentage of the method recovery, which was $97.26 \%$.

The soil samples, after going through the removal of extractable residues, were autoclaved at $120^{\circ} \mathrm{C}$ and $9.8 \times 10^{4} \mathrm{~Pa}$ pressure, for 30 minutes, for three days in a row to release bound residues. Later, the samples went through the same process of extraction with methanol, as previously described.

Atrazine concentration in extracts was determined by high-performance liquid chromatography (HPLC) techniques. The samples were filtered in a filter unit with a membrane of $0.45 \mu \mathrm{m}$ pores and then injected into chromatograph, according to the following conditions: column C-18 (150 x $4.6 \mathrm{~mm})$, mobile stage methanol: water (50:50, v/v), UV detector $-230 \mathrm{~nm}$, continuous flow of $1 \mathrm{~mL} \mathrm{~min}^{-1}$, furnace temperature of $35^{\circ} \mathrm{C}, 15$ minutes run and injection volume of $20 \mu \mathrm{L}$. 
The amount of dissipated atrazine was calculated according to the difference between the initial concentration of applied atrazine and the sum of extractable and bound residues concentrations after the incubation period.

\section{Data analyses}

The treatments were established in a $2 \times 2$ factorial scheme in a complete randomized lineation, with 5 replications, adding up to 20 experimental plots. The obtained data were subjected to variance analysis and to the multiple mean comparison test, by using Scott-Knott Test at $5 \%$ of significance.

\section{RESULTS AND DISCUSSION}

The obtained data presented normality according to Anderson-Darling test at $5 \%$ of significance and there was no interaction among the studied factors in none of the analyzed parameters, so that only the medium concentration of bound residues showed significant difference among the treatments (Table 3).

TABLE 3. P-value values for extractable residue, bound residue and atrazine dissipated in soil.

\begin{tabular}{cccc}
\hline Variation source & Extractable residue & Bound residue & Dissipated atrazine \\
\hline Water $(\mathrm{A})^{1}$ & $0.87^{\mathrm{ns}}$ & $0.00^{*}$ & $0.53^{\mathrm{ns}}$ \\
Sterilization $(\mathrm{E})^{2}$ & $0.32^{\mathrm{ns}}$ & $0.10^{\mathrm{ns}}$ & $0.44^{\mathrm{ns}}$ \\
Interaction $(\mathrm{A} x \mathrm{E})^{\text {C.V. }(\%)}$ & $0.22^{\mathrm{ns}}$ & $0.89^{\mathrm{ns}}$ & $0.20^{\mathrm{ns}}$ \\
\hline General mean & 22.55 & 22.67 & 23.58 \\
\hline
\end{tabular}

* Significant at 5\% probability; "ns" not significant. ${ }^{1}$ Two levels of water added: distilled water or SW; ${ }^{2}$ Two levels of sterilization: sterile or non-sterile soil.

The results for the extractable residues corresponded, in treatments $\mathrm{T} 1, \mathrm{~T} 2, \mathrm{~T} 3$ and $\mathrm{T} 4$, at $43.3 \%, 54.3 \%, 45.4 \%$ and $37.1 \%$, to atrazine initially applied to soil, respectively (Table 4). The amount of remaining extractable residues after the incubation period is an indicative of atrazine biodegradation and formation of bound residues. Treatment T4, in which the soil did not go through the process of sterilization, presented the lowest mean value for extractable residues, indicating that a biological degradation of atrazine occurred. This result corroborates with MUNIER-LAMY et al. (2002), who also observed that the presence of the natural soil microbiota led to a decrease in the amount of extractable residues of atrazine after 120 days of incubation.

TABLE 4. Average concentration of extractable residue, bound residue and atrazine dissipated in soil after 60 days of incubation.

\begin{tabular}{cccc}
\hline Treatment & $\begin{array}{r}\text { Extractable residue } \\
\left(\mathrm{mg} \mathrm{kg}^{-1}\right)\end{array}$ & $\begin{array}{r}\text { Bound residue } \\
\left(\mathrm{mg} \mathrm{kg}^{-1}\right)\end{array}$ & $\begin{array}{r}\text { Dissipated atrazine } \\
\left(\mathrm{mg} \mathrm{kg}^{-1}\right)\end{array}$ \\
\hline T1 & $73.24^{\mathrm{a}}$ & $20.60^{\mathrm{b}}$ & $74.78^{\mathrm{a}}$ \\
T2 & $91.51^{\mathrm{a}}$ & $10.77^{\mathrm{a}}$ & $66.33^{\mathrm{a}}$ \\
T3 & $76.59^{\mathrm{a}}$ & $23.92^{\mathrm{b}}$ & $68.10^{\mathrm{a}}$ \\
T4 & $62.62^{\mathrm{a}}$ & $13.60^{\mathrm{a}}$ & $92.39^{\mathrm{a}}$ \\
\hline
\end{tabular}

The means followed by the same letter in the column do not differ among themselves at 5\% significance by the Scott-Knott Test.

The application of swine wastewater in soil influenced the formation of bound residues (Table 4). The organic material on soil along with organic material from the added swine wastewater promoted an increase in the formation of atrazine bound residues. The presence of organic matter in swine wastewater was expressed from the values of BOD, COD and TOC (Table 2) and approached the values found by DAL BOSCO et al. (2008) and SAMPAIO et al. (2010a). According to KHAN (1991), the organic material is the main site of formation of atrazine bound residues. The herbicide and its products of degradation are strongly retained by humid fractions, probably by a process that 
involves sorption of the external surfaces and penetration of the internal voids of links among molecules with a sieve-like structure. In this context, WANG \& KELLER (2009), studying sorption and desorption of atrazine and diuron in soil fractions, have mentioned that, due to their higher soil organic carbon content, clay fractions were much more effective sorbents for pesticides than silt and sand fractions.

Studies have shown increased formation of bound residues of herbicides in soils receiving organic materials. HOUOT et al. (1998) reported that the addition of compounds of solid urban residues and composted straw residues to the soil increased the formation of non-extractable atrazine residues. DAMIN (2005) observed higher formation of bound diuron residues in samples of Rhodic Hapludox soil with clay-like texture, added with sewage sludge, corroborating with the results shown on Table 4.

There was no significant difference among the treatments for dissipated atrazine, which shows that there was no effect of swine wastewater application. BRICEÑO et al. (2010) also found that cow slurry applications had no effect on atrazine dissipation. It can be observed that soil with natural microbiota and without addition of swine wastewater (Treatment T4) showed a higher mean value of atrazine dissipation, besides, the lowest mean value of extractable residue, evidenced biological degradation during the incubation period. In an experiment performed by NAKAGAWA \& ANDRÉA (2000), biomineralization of atrazine was detected only in soil with natural microbiota, when compared to the sterilized soil and contaminated with pure culture of Pseudomonas putida.

In soils that received $\mathrm{SW}$, atrazine dissipation was lower when compared to the natural soil (treatment T4). Such circumstance possibly occurred due to the fact that the addition of organic materials to the soil may influence on the atrazine degradation rate, either by the providence of nutrients that stimulate or suppress the degrading microorganisms, or by the reduction in atrazine bioavailability, due to the increase in the sorption of atrazine residues in the additional organic material (HOUOT et al., 1998; BIGWANEZA et al., 2003; AGUILERA et al., 2009; BRICEÑO et al., 2008). Treatment T2 showed the lowest value of atrazine dissipated, possibly due to the sterilization process, which corroborates the results found by KE-BIN et al. (2008).

It was observed that the formation of bound residues was larger in the treatments that received swine wastewater (T1 and T3), decreasing atrazine bioavailability in soil and complicating mineralization. The formation of bound residues has a great importance in studies about pesticides fate in the environment, because when these residues are formed, bioavailability decreases and, as consequence, its dissipation is also biologically reduced (MUDHOO \& GARG, 2011). BIGWANEZA et al. (2003) reported that swine wastewater application and treated sewage to soil did not show significant effects on atrazine dissipation, in which adsorption was positively correlated to the amount of organic material in fertigated soils.

Considering soils which received application of SW, the sterile soil (T1) showed a higher value of dissipated atrazine in relation to the non-sterile soil (T3), with a possible occurrence of competition among the species of microorganisms involved. Atrazine degradation may be reinforced by the synergism among the species in the swine wastewater and soil microbiota, but on the other hand, the degradation activity may be negatively influenced by antagonistic soil microorganisms. The antagonism is not linked to a unique mechanism of action, but to associations of mechanisms such as antibiosis, competition for nutrients, direct interaction with the species, predation or resistance induction (MENDEZ \& MONDINO, 1999). SHAPIR et al. (2000) observed that the addition of sewage sludge to the soil along with fertigation with treated sewage, aiming to achieve atrazine mineralization, increased the competition among native populations of the soil and the added bacteria. Thus, soil microorganisms that are better adapted to the environment may repress the activity and maybe even the capacity of microorganism's survival, added via SW.

According to the obtained results, it was observed that there was atrazine dissipation also in the sterile soil with only the addition of distilled water. Abiotic activities, as chemical oxidation 
reactions, reduction and hydrolysis, can also contribute to the transformation and dissipation of atrazine in soil, besides microbiological degradation. The main mechanism of chemical reaction in the pesticide transformation on soil is hydrolysis, which is influenced by the pesticide $\mathrm{pH}$ value, temperature and sorption. In this case, in treatment $\mathrm{T} 2$, the atrazine transformation may have occurred by chemical processes (HOUOT et al., 1998; NAKAGAWA \& ANDRÉA, 2000; DOLAPTSOGLOU et al., 2007).

\section{CONCLUSIONS}

From the obtained results, it is possible to conclude that:

- The application of swine wastewater showed no effects on atrazine dissipation in Rhodic Hapludox soil;

- The addition of swine wastewater to the soil favored an increase in the formation of bound residues, which may raise atrazine persistence in the environment and reduce its availability to plants and to biological degradation.

\section{ACKNOWLEDGEMENTS}

To "Fundação Araucária de Apoio ao Desenvolvimento Científico e Tecnológico" for financing the project, to "Coordenação de Aperfeiçoamento de Pessoal de Nível Superior (CAPES)" and to "Conselho Nacional Científico e Tecnológico (CNPq)" for providing the scholarhip.

\section{REFERENCES}

AGUILERA, P.; BRICEÑO, G.; CANDIA, M.; MORA, M.; DEMANET, R.; PALMA, G. Effect of dairy manure rate and the stabilization time of amended soils on atrazine degradation.

Chemosphere, Kidlington, v.77, n.6, p.785-790, 2009.

ANAMI, M.H.; SAMPAIO, S.C.; GOMES, S.D.; QUEIROZ, M.M.F. Deslocamento miscível de nitrato e fosfato proveniente de água residuária da suinocultura em colunas de solo. Revista Brasileira de Engenharia Agrícola e Ambiental, Campina Grande, v.12, n.1, p.75-80, 2008.

ANAMI, M.H.; SAMPAIO, S.C.; SUSZEK, M.; FRIGO, E.P. Lixiviação de nitrato e fosfato proveniente de água residuária da suinocultura tratada em sistema de lagoas. Irriga, Botucatu, v.12, n.2, p. 192-201, 2007.

BARRACLOUGH, D.; KEARNEY, T.; CROXFORD, A. Bound residues: environmental solution or future problem? Environmental Pollution, Madison, v.133, p.85-90, 2005.

BAUMGARTNER, D.; SAMPAIO, S.C.; SILVA, T.R.; TEO, C.R.P.A.; BOAS, M.A.V. Reúso de águas residuárias da piscicultura e da suinocultura na irrigação da cultura da alface, Engenharia Agrícola, Jaboticabal, v.27, n.1, p.152-163, 2007.

BIGWANEZA, P.; FORTIN, J.; ANTOUN, H.; NDAYEGAMIYE, A. Effect of long-term liquid pig manure application on atrazine mineralization in a soil cultivated with maize. Biology and Fertility of Soils, Heidelberg, v. 38, n.4, p.191-199, 2003.

BRICEÑO G.; JORQUERA, M.A.; DEMANET, R.; MORA, M.L.; DURÁN, N.; PALMA, G. Effect of cow slurry amendment on atrazine dissipation and bacterial community structure in an agricultural Andisol. Science of the Total Environment, Amsterdam, v.408, p. 2833-2839, 2010.

BRICEÑO, G.; DEMANET, R.; MORA, M.; PALMA, G. Effect of liquid cow manure on andisol properties and atrazine adsorption. Journal of Environmental Quality, Madison, v.37, p.1519-1526, 2008.

CAOVILLA, F.A.; SAMPAIO, S.C.; SMANHOTTO, A.; NOBREGA, L.H.P.; QUEIROZ, M.M. F. DE;GOMES, B.M. Características químicas de solo cultivado com soja e irrigado com água 
residuária da suinocultura. Revista Brasileira de Engenharia Agrícola e Ambiental, Campina Grande, v. 14, n.7, p. 692-697, 2010.

COLLA, L.; PRIMAZ, A.; LIMA, M.; BERTOLIN, T.; COSTA, J. Isolamento e seleção de fungos para biorremediação a partir de solo contaminado com herbicidas triazínicos. Ciência e Agrotecnologia, Lavras, v.32, n.3, p.809-813, 2008.

DAL BOSCO, T.C.; IOST, C.; SILVA, L. N. DA; CARNELOSSI, C.F.; EBERT, D.C.;

SCHREINER, J.S.; SAMPAIO, S.C. Utilização de água residuária de suinocultura em propriedade agrícola estudo de caso, Irriga, Botucatu, v. 13, n.1, p. 139-144, 2008.

DAL BOSCO, T.C.; SAMPAIO, S.C.; OPAZO, M.A.U.; NÓBREGA, L.H.P. Aplicação de água residuária de suinocultura em solo cultivado com soja: cobre e zinco no material escoado e no solo. Engenharia Agrícola, Jaboticabal, v.28, n.4, p.699-709, 2008.

DAMIN, V. Biodegrdação, sorção e dessorção do herbicida ${ }^{14}$ CDiuron em dois latossolos tratados com lodo de es goto. 2005. 83 f. Dissertação (Mestrado em Agronomia) - Escola Superior de Agricultura "Luiz de Queiroz”, Universidade de São Paulo, Piracicaba, 2005.

DOBLINSKI, A. F.; SAMPAIO, S.C.; SILVA, V.R.DA ; NÓBREGA, L.H. P. ; GOMES, S.D.; DAL BOSCO, T.C. Nonpoint source pollution by swine farming wastewater in bean crop. Revista Brasileira de Engenharia Agrícola e Ambiental, Campina Grande, v. 14, n.1, p. 87-93, 2010.

DOLAPTSOGLOU, C.; KARPOUZAS, D.G.; MENKISSOGLU-SPIROUDI, U.;

ELEFTHEROHORINOS, I.; VOUDRIAS, E.A. Influence of different organic amendments on the degradation, metabolism, and adsorption of terbuthylazine. Journal of Environmental Quality, Madison, v.36, p. 1793-1802, 2007.

EMBRAPA. EMPRESA BRASILEIRA DE PESQUISA AGROPECUÁRIA. Centro Nacional de Pesquisas de Solos. Sistema brasileiro de classificação de solos. 2.ed. Rio de Janeiro, 2006. 306 p.

FAVA, L.; ORRÙ, M.; SCARDALA, S.; FUNARI, E. Leaching potential of carbamates and their metabolites and comparison with triazines. Microchemical Journal, New York, v.86, n.2, p.204208, 2007.

FRIGO, E.P.; SAMPAIO, S.C.; FREITAS, P.S.L.DE; QUEIROZ, M.M.F. DE; NÓBREGA, L.H.P.; MALLMANN, L.S. Desempenho do sistema de gotejamento e de filtros utilizando água residuária da suinocultura, Irriga, Botucatu, v. 11, n.3, p. 305-318, 2006.

GHOSH, P.; PHILIP, L. Environmental significance of atrazine in aqueous systems and its removal by biological processes: an overview. Global NEST Journal, Greece, v.8, n.2, p.159-178, 2006.

HOUOT, S.; BARRIUSO, E.; BERGHEAUD, V. Modification to atrazine degradation pathways in loamy soil after addition of organic amendments. Soil Biology and Biochemistry, Oxford, v.30, n.4, p.2147-2157, 1998.

KADIAN, N.; GUPTA, A.; SATYA, S.; MEHTA, R.; MALIK, A. Biodegradation of herbicide (atrazine) in contaminated soil using various bioprocessed materials. Bioresource Technology, Oxon, v.99, n.11, p.4642-4647, 2008.

KE-BIN, L.; JING-TAO, C.; XIAO-FANG, W.; YING, Z.; WEI-PING, L. Degradation of herbicides atrazine and bentazone applied alone and in combination in soils. Pedosphere, Beijing, v.18, n.2, p.265-272, 2008.

KHAN, S.U. Bound (nonextractable) pesticide degradation products in soils. In:

SOMASSUNDARAM, L.; COATS, J.R. Pesticide transformation products: fate and significance in the environment. Washington: ACS, 1991. p.108-121.

LIMA, D.; VIANA, P.; ANDRÉ, S.; CHELINHO, S.; COSTA, C.; RIBEIRO, R.; SOUSA, J.; FIALHO, A.; VIEGAS, C. Evaluating a bioremediation tool for atrazine contaminated soils in open 
soil microcosms: the effectiveness of bioaugmentation and biostimulation approaches. Chemosphere, Kidlington, v.74, n.2, p.187-192, 2009.

MAGGI, C.F; FREITAS, P.S.L. DE; SAMPAIO, S.C.; DIETER, J. Lixiviação de nutrientes em solo cultivado via aplicação de água residuária de suinocultura. Revista Brasileira de Engenharia Agrícola e Ambiental, Campina Grande, v. 15, n.2, p. 170-177, 2011.

MENDEZ, S.; MONDINO, P. Control biologico postcosecha en Uruguay. Horticultura Internacional, v.7, p.29-36, 1999.

MUDHOO, A.; GARG, V.K. Sorption, transport and transformation of atrazine in soils, minerals and composts: a review. Pedosphere, Beijing, v.21, n.1, p.11-25, 2011.

MÜLLER, K.; MAGESAN, G.; BOLAN, N. A critical review of the influence of effluent irrigation on the fate of pesticides in soil. Agriculture, Ecosystems and Environment, Amsterdan, v.120, n.2-4, p.93-116, 2007.

MUNIER-LAMY, C.; FEUVRIER, M.P.; CHONÉ, T. Degradation of 14C-Atrazine bound residues in brown soil and rendzina fractions. Journal of Environmental Quality, Madison, v.31, p.241-247, 2002.

NAKAGAWA, L.; ANDRÉA, M. Degradação e formação de resíduos não-extraíveis ou ligados do herbicida atrazina em solo. Pesquisa Agropecuária Brasileira, Brasília, v. 35, n.8, p.1509-1515, 2000.

OSMAN, K.; AL-REHIAYANI, S.; AL-DEGHAIRI, M.; SALAMA, A. Bioremediation of oxamyl in sandy soil using animal manures. International Biodeterioration \& Biodegradation, Birmingham, v.63, n.3, p.341-346, 2009.

PELISSARI, R.; SAMPAIO, S.C.; GOMES, S.D.; CREPALLI, M.S. Lodo têxtil e água residuária da suinocultura na produção de mudas de Eucalyptus grandis (W, Hill ex Maiden). Engenharia Agrícola, Jaboticabal, v.29, n.2, p.288-300, 2009.

PRIOR, M.; SMANHOTTO, A.; SAMPAIO, S.C.; NOBREGA, L.H.P.; OPAZO, M.A.U.; DIETER, J. Acúmulo e percolação de fósforo no solo devido à aplicação de água residuária de suinocultura na cultura do milho (Zea mays L.). Revista Brasileira de Tecnologia Aplicada nas Ciências Agrárias, Guarapuava, v. 2, n.1, p. 89-96, 2009.

SAMPAIO, S.C. ; FIORI, M.G.S.; OPAZO, M.A.U.; NÓBREGA, L.H.P. Comportamento das formas de nitrogênio em solo cultivado com milho irrigado com água residuária da suinocultura. Engenharia Agrícola, Jaboticabal, v. 30, n.1, p. 138-149, 2010a.

SAMPAIO, S.C.; CAOVILLA, F.A.; OPAZO, M.A.U.; NÓBREGA, L.H.P.; SUSZEK, M.; SMANHOTTO, A. Lixiviação de íons em colunas de solo deformado e indeformado. Engenharia Agrícola, Jaboticabal, v. 30, n.1, p. 150-159, 2010 b.

SAMPAIO, S.C.; SUSZEK, M.; GOMES S.D.; FAZOLO, A. Calibração de um diafragma utilizando água residuária da bovinocultura e suinocultura. Varia Scientia Agrárias, Cascavel, v. 1, n.1, p. 81-86, 2010c.

SAMPAIO, S.C.; FRIGO, E.P.; VILAS-BOAS, M.A.; QUEIROZ, M.M.F. DE; GOMES, B.M. Perda de carga em tubulações e conexões conduzindo água residuaria da avicultura. Irriga, Botucatu,v. 12, n. 2, p. 20-34, 2007a.

SAMPAIO, S.C.; MATIAS, K.C.; VILAS-BOAS, M.A.; QUEIROZ, M.M.F. DE; GOMES, B. M. Equação de Hazen-Williams corrigida para água residuária proveniente da suinocultura. Revista Brasileira de Engenharia Agrícola e Ambiental, Campina Grande, v. 11, n.1, p. 5-10, 2007b.

SHAPIR, N.; MANDELBAUM, R.; FINE, P. Atrazine mineralization by indigenous and introduced Pseudomonas sp. strain ADP in sand irrigated with municipal wastewater and amended with composted sludge. Soil Biology and Biochemistry, Oxford, v.32, n.7 p.887-897, 2000. 
SMANHOTTO, A.; SOUSA, A. DE P; SAMPAIO, S.C; NÓBREGA, L.H.P; PRIOR, M.; Cobre e zinco no material percolado e no solo com a aplicação de água residuaria de suinocultura em solo cultivado com soja. Engenharia Agrícola, Jaboticabal, v. 30, n.2, p. 347-357, 2010.

SUSZEK, M.; SAMPAIO, S.C.; MALLMANN, L.S; SILVESTRO, M.G. Aspectos físicos e químicos de vermicompostos produzidos a partir de esterco bovino e compostos de resíduos verdes urbanos. Engenharia na Agricultura, Viçosa, v. 15, n.1, p. 39-44, 2007.

TSUI, L.; ROY, W. Effect of compost age and composition on the atrazine removal from solution. Journal of Hazardous Materials, Amsterdan, v.139, n.1, p.79-85, 2007.

WANG, H.; LI, Y.; LU, Y.; HUANG, C.; ZHANG, M.; WANG, X. Influence of bovine manure on dissipation of hexazinone in soil. Ecotoxicology and Environmental Safety, New York, v.72, n.1, p.93-98, 2009.

WANG, P.; KELLER, A.A. Sorption and desorption of atrazine and diuron onto water dispersible soil primary size fractions. Water Research, Oxford, v.43, p.1448-1456, 2009. 